\title{
Erratum to: A disorder of surfactant metabolism without identified genetic mutations
}

Silvia Montella ${ }^{1}$, Timothy J. Vece ${ }^{2}$, Claire Langston ${ }^{3}$, Paola Carrera ${ }^{4}$, Lawrence M. Nogee ${ }^{5}$, Aaron Hamvas ${ }^{6,7}$, Angelo Manna ${ }^{1}$, Mariarosaria Cervasio $^{8}$ and Francesca Santamaria ${ }^{1 *}$

Unfortunately, the original version of this article [1] contained an error. The name of one of the authors was included incorrectly and it read "Mara Cervasio" instead of "Mariarosaria Cervasio".

The name has been updated in the original article and is also correctly included in full in this erratum.

\begin{abstract}
Author details
'Department of Translational Medical Sciences, Federico II University, Via Sergio Pansini, Naples 5 - 80131, Italy. ${ }^{2}$ Department of Pediatrics, Baylor College of Medicine, Texas Children's Hospital, Houston, TX, USA. ${ }^{3}$ Department of Pathology, Baylor College of Medicine, Texas Children's Hospital, Houston, TX, USA. ${ }^{4}$ Division of Genetics and Cell Biology, IRCCS Ospedale San Raffaele, Milano, Italy. ${ }^{5}$ Division of Neonatology, Department of Pediatrics, Johns Hopkins University School of Medicine, Baltimore, MD, USA. ${ }^{6}$ Division of Newborn Medicine, Edward Mallinckrodt Department of Pediatrics, Washington University School of Medicine, St. Louis, MO, USA. ${ }^{7}$ Division of Neonatology, Department of Pediatrics, Ann and Robert H. Lurie Children's Hospital of Chicago, Northwestern University Feinberg School of Medicine, Chicago IL, USA. ${ }^{8}$ Department of Advanced Biomedical Sciences, Anatomo-Pathology Unit, Federico II University, Naples, Italy.
\end{abstract}

Received: 10 December 2015 Accepted: 10 December 2015

Published online: 16 December 2015

\section{Reference}

1. Montella S, Vece TJ, Langston C, Carrera P, Nogee LM, Hamvas A, et al. A disorder of surfactant metabolism without identified genetic mutations. Ital J Pediatr. 2015;41:93.

\footnotetext{
*Correspondence: santamar@unina.it

'Department of Translational Medical Sciences, Federico II University, Via Sergio Pansini, Naples 5 - 80131, Italy

Full list of author information is available at the end of the article
}

Submit your next manuscript to BioMed Central and we will help you at every step:

- We accept pre-submission inquiries

- Our selector tool helps you to find the most relevant journal

- We provide round the clock customer support

- Convenient online submission

- Thorough peer review

- Inclusion in PubMed and all major indexing services

- Maximum visibility for your research

Submit your manuscript at www.biomedcentral.com/submit 